\title{
Babbage the unfortunate
}

\section{R Keeler}

\section{But for the addition of a 4 or 5 dioptre concave lens in his instrument for looking into the eye, Babbage would probably be renowned today as the harbinger of the modern era of ophthalmology}

r 1850, Hermann von Helmholtz revolutionised ophthalmology by the invention of an eye speculum or ophthalmoscope. Yet, 3 years earlier, an Englishman, Charles Babbage came so near to claiming this great prize.

Charles Babbage was born in 1791 into a wealthy London banking family. A delicate child, ill health was to dog his long life. He showed an early aptitude for mathematics and became Lucasian Professor of Mathematics at Cambridge, a chair held previously by Sir Isaac Newton; he held it for 10 years without giving a lecture.

He married Georgiana Whitmore against his father's wishes, but inherited a fortune from him, freeing him to indulge in his passion for mathematics and mechanics.

Why should Babbage attempt to construct an instrument for looking into the eye? He was alleged to have had bilateral monocular diplopia-did this create an inquisitiveness to explore his own eyes? Or was there some other reason?

An article on Babbage in $1940^{1}$ provides a clue about his defective eyesight. He had made two excursions into ophthalmology - the ophthalmoscope and colour vision. Alfred Smee, ophthalmic surgeon to the Bank of England, suggested in $1847^{2}$ that the great William Mackenzie had asserted that Babbage had "irregular vision."

Alfred Smee, co-founder of the Central London Ophthalmic Hospital, was an ophthalmologist polymath, and a pioneer of artificial intelligence. Smee was the son of the chief accountant of the Bank of England and Babbage was once called in to advise him on how to combat forgery of bank notes.

There are several editions of William Mackenzie's Practical Treatise on the Diseases of the Eye between 1830 and 1854; there is no reference to Babbage in the first but, in the 1834 edition, Babbage is mentioned. "M(onsieur). Prévost, at the age of 81 years, has published an interesting account of his own case of double vision with a single eye, which he thinks may perhaps arise from a fracture, bruise or partial flattening of the lens or separation of its laminae"..... "Prévost has also communicated with Mr Babbage who is affected in either eye singly with double vision, a defect however which he finds himself able to remedy by looking through a small hole in a card or through a concave lens." Mackenzie cites Pierre Prévost's communications with Babbage in Annales de Chimie et de Physique 1832.

\section{THE PRÉ VOST FAMILY}

The extensive Prévost family contributed much to science and ophthalmology. Attempts had been made to view the interior of the eye and to explain the reflexes coming from it and why the eye demonstrated luminosity under certain conditions. These theories were vague and included fantastic speculations: was the fleeting luminosity phosphorescence, light absorbed during the day giving off light at night like a firefly, or was it naked electricity emitted by the retina?

In 1810 Benedict Prévost affirmed that the retina could not be seen in the dark; it was the reflection of light which entered the eye from without which gave it luminosity.

Isaac Benedict Prévost, Pierre's first cousin, was born in Geneva but became an academic in Montaubon in France. Babbage would have known or been aware of him, being a fellow scientist. Pierre Prévost had three sons, Alexandre, ${ }^{5}$ Jean-Louis, ${ }^{6}$ and Guillaume. The first two wrote on ophthalmological subjects. Babbage named his younger son Henry Prévost but it is unclear which Prévost was so honoured

Pierre Prévost, a Swiss physicist, showed that all bodies, hot or cold, radiate heat ${ }^{7}$ and gave the name Daltonism to colour deficiencies. When he presented "The doubling of an object by one eye on its own" in 1832 he was Professor Emeritus in Geneva, studying the ageing process with himself as the subject. Finding they shared an ailment
Prévost and Babbage exchanged information about this unusual eye condition. The following is a translation from the French of part of Babbage's observations to Prévost.

"I see two images of objects, vertically one above the other, with two eyes, or with each eye separately, each time that I look at an object without forcing the organ. The superior image is weaker than the inferior image, the real one and is separated by an angle of 12 minutes.

When I am in bad health, the second image becomes stronger; but the angular distance is, I believe, not altered.

"Because of the small separation of the two images, nearby objects do not appear doubled, but an indistinction manifests itself at the edges. The more noticeable object is the remote horizon, which always appears doubled. The stars, to my eyes, are so indistinct, that I am unable to say if I see them doubled but rather cloudy. I noticed this fact for the first time when I was observing the horizon on my travels.

"When I look through a small hole made in a card, or through a small opening between my fingers and thumb (as I very often do to see more clearly) I lose the weaker image. I can also get rid of it when inclining my head backwards and aiming my view under the eyelid, in the manner that the rays coming from the object are very close to it.

"I see only one object if I look with one eye through a concave lens. I can also get rid of the second image when frowning, but that needs quite an effort."

Babbage's common interests with the Prévosts may have encouraged him to construct an ophthalmoscope in 1847 for examination of his own eyes. At that time the word ophthalmoscope was unknown.

\section{WILLIAM CUMMING}

In 1846, William Cumming wrote "On a luminous appearance of the human eye and its application to the detection of disease of the retina and posterior part of the eye, ${ }^{\prime \prime}$ the first paper to explain that the axis of illumination and observation had to be coincident to view the fundus.

There is no evidence that Babbage knew of Cumming's paper but in the buzzing scientific community in London, it is likely that Cumming's paper was read by Babbage who would have realised how to visualise the fundus.

In the manuscript room of the British Library there are 19 volumes of letters to Babbage and drafts from him totalling over 10000 letters. I have looked for clues about Babbage's defective eyesight and reference to an instrument for 
looking into the eye. In all the biographies and Babbage's own semi-autobiography, Passages from a Life of a Philosopher, ${ }^{9}$ there is not one mention of either. Babbage scholars are unaware that Babbage had an eye defect.

\section{BABBAGE'S "OPHTHALMOSCOPE"}

Why did Babbage show his instrument to Thomas Wharton Jones and not Cumming if he knew him, or indeed the Prévosts?

Thomas Wharton Jones studied in Edinburgh but left after being unwittingly implicated in the Burke and Hare body snatching scandal. He moved to Glasgow and joined William Mackenzie whom he provided with sectional anatomical drawings of the eye for his classic treatise.

Mackenzie knew Babbage had an eye defect and it is possible that he recommended him to see his protégé Wharton Jones, now an outstanding oculist in London, who Edward Jenner had called one of the greatest Englishmen who ever lived.

Wharton Jones, in 1847, confessed to having tried the instrument and rejected it as of little value and we have to rely on him for a description of Babbage's ophthalmoscope. ${ }^{10}$ The model consisted of a piece of plain mirror, with the silvering scraped off at two or three small spots in the centre, held within a tube at an angle so that rays of light falling on it through an opening in the side were reflected into the patient's eye. The observer looked through the clear spots of the mirror from the other end.

Wharton Jones was a poor choice to review the instrument: he was still sceptical of the value of an ophthalmoscope 3 years after it was in common use, deeming the light dangerous to the retina, and he was a myope. Critically, what Babbage missed in his design, which Helmholtz realised, was the need for a concave lens between the observer's eye and the back of the mirror to correct the convergent rays from the patient's retina. Although Babbage used a plano mirror with an aperture instead of parallel glass slides as employed by Helmholtz, the optics were essentially the same. The rays reflected from the subject's eye will, depending on the refraction of the eye and the patient's accommodation, be convergent. By placing a concave lens in front of the observer's eye, the rays can be given divergence so that the observer, if accommodating, can bring them to a focus. The observer would have had to contend with an area of illumination of approximately 5 degrees, exacerbating an already difficult procedure. With his myopia, Wharton Jones probably saw only a small, weak red reflex, so he rejected the instrument as unworkable. Babbage did not pursue his invention.

\section{COLOUR VISION}

Babbage's second foray into ophthalmology was with colour vision.

In 1827, when he published his Specimen of Logarithmic Tables it was printed on coloured paper. ${ }^{11}$ He experimented with no less than 151 different coloured papers before deciding on an ochreous yellow tint, claiming that the human eye could tolerate lengthy readings of these tables better with this.

In 1859, the Ophthalmic Hospital Reports and Journal of the Royal London Ophthalmic Hospital was printed on yellow paper with the editor J F Streatfield giving generous space to Babbage's rules of typographical perspicuity. ${ }^{12}$

\section{BABBAGE'S MECHANICAL CALCULATOR}

Up to the time that Babbage was constructing his ophthalmoscope in 1847 he was battling the government for funds for the development of his analytical machine. George Airy, the Astronomer Royal, questioned the need for mechanisation over conventional manual calculation and referred to Babbage's machine as "this thing is a humbug."

By 1847 Babbage had become substantially a master of mechanical calculation and was concentrating on the design of his Difference Engine No 2, which was under construction.

The unfortunate Babbage's brilliant concept was vindicated 100 years after his death when his Difference Engine was painstakingly built at the Science Museum in London from his drawings, left by his son Henry. It worked perfectly! $!^{13}$ This most beautiful machine calculates to 30 decimal points and prints out the results.

Babbage was a Victorian polymath but his personal life was one of unrelieved sadness. He had eight children: only three survived. In 1827 his father, his wife, and two children died. His beloved daughter Georgiana died in 1834; he never recovered from this.

From a very early age Babbage was inventing, solving riddles, and experimenting. He nearly drowned in childhood trying out foot paddles with connecting hinges hoping that, with their pumping action, he could walk on water. His signalling lights, the occulting telegraph, were copied by the Russians and used at Sebastopol. He devised methods of using colour filters in the theatre with advice from Michael Faraday.

\section{BRILLIANT FRIENDS}

In the 1840s and 1850s Babbage was lionised by society in London and was a sociable person, holding soirées of 200300 people at his home in Dorset Street.

For amusement, he became a master lock picker and broke the code of the "unbreakable" 300 year old Vigenère Cipher in just 2 weeks at the beginning of the Crimean War.

Among the letters in the British Library are ones from Charles Dickens to whom Ada, Countess of Lovelace, was greatly attracted. Early American computer software was named Ada after her. There is a letter from Mendelsohn declining a soirée because of headache brought on by 6 hours of rehearsing. There are many exchanges with Brunel from whom Babbage's advice was sought on the Great Western Railway.

His contacts with the men of science and medicine of the day were many: Sir William Wollaston, Sir Michael Faraday, Sir John Herschel, Charles Wheatstone, Augustin Fresnel, and the Reverend William Whewell, who coined the word astigmatism and introduced the word "scientist." Correspondence with men of medicine included Richard Owen and Sir Joseph Lister, inquiring about the use of polarising nicol prisms for his work on antisepsis.

There are letters from William Fox Talbot the father of modern photography in 1839 and Antoine Claudet the great portraitist using the Daguerre process. His closest friend, John Herschel, discovered the Prussian blue cyanotype the first method of photocopying; Alfred Smee unknowingly provided him with the potassium ferricyanide essential for this process.

There is a fascinating letter in $1824^{14}$ by Sir David Brewster, inventor among other things of the kaleidoscope, and discovered the polarisation of light, which reads "I am busy at present with the examination of the lenses of fishes but I am unable to get those of the carp and tench. It has occurred to me that they may be available in London"......"the immersion of the lens for a few minutes in very hot water will allow them to be wrapt up with safety in a piece of paper." He thanked Babbage for "the very curious and interesting compilation in optics from which I have no doubt we shall derive much light upon the early history of the science." This is Scriptores Optici ${ }^{15}$ which, edited by Babbage, consists of papers by Huygens, Descartes, Halley, Barrow, and others. Brewster was interested in an instrument for looking in the eye and Babbage's frequent correspondence with him might also provide a clue for Babbage's construction.

Babbage sought recognition for his public services but he had made enemies of too many powerful people with his obstinacy and intransigence and his 
ambitions were beyond what the government was prepared to offer. Most of his contemporaries had received knighthoods. No less than a peerage would have satisfied him-instead he died alone aged 79 unfulfilled, bitter, in poor health, and tormented even on his deathbed by the sound of Italian organ grinders, whom he'd described as a public nuisance.

His curiosity in scientific invention remained late in life. He said he would gladly have given up the remainder of his life if he could be allowed to live 3 days, 500 years hence assisted by a scientific Cicerone who could explain to him the discoveries made since his death.

Charles Babbage was buried in Kensal Green Cemetery, London in 1871, the funeral attracting just one carriage. At his suggestion his brain had been removed and given to the Royal College of Surgeons for research.
But for the addition of a 4 or 5 dioptre concave lens in his instrument for looking into the eye, Babbage would probably be renowned today as the harbinger of the modern era of ophthalmology.

Br J Ophthalmol 2004:88:730-732. doi: $10.1136 /$ bjo.2003.018564

Correspondence to: C R Keeler, Royal College of Ophthalmologists, London, UK; rkeeler@freenetname.co.uk

Accepted for publication 16 December 2003

\section{REFERENCES}

1 Barnett A. The ophthalmic inventions of Charles Babbage. The Refractionist 1940;May: 141-3.

2 Smee A. Vision in health and disease. Ophthalmic Hospital Reports 1847:30.

3 Mackenzie W. A practical treatise on the diseases of the eye. London: Longman, Rees, Orme, Brown, Green \& Longman, 1835;20:855.

4 Prévost P. Doublement d'un objet par un oeil unique. Annales de Chimie et de Physique 1832;51:210.
5 Prévost AP. Essai sur la théorie de la vision binoculaire. Geneve: Fend. Ramboz, 1843.

6 Prévost JL. De la deviation conjuguée des yeux et de la rotation de la tete dans certains cas d'héméplégie. Paris: Victor Masson et Fils, 1868

7 Prévost P. Dictionary of scientific biography 1970-1976. Charles Coulston Gillespie, ed. New York: Charles Scribner.

8 Cumming W. On a luminous appearance of the human eye. Trans Med Chir Soc 1846;29:283.

9 Babbage C. Passages from the life

of a philosopher. London: Longman, Green, Longman, Robert \& Green, 1864.

10 Wharton Jones T. Br Foreign Med Chir Rev 1854;XIV(October):425-32.

11 Babbage C. Specimen of logarithmic tables. An account. Ed Jour of Science (Brewster's) 1832; Vl: 144.

12 Streatfield JF. On coloured paper. Ophthalmic Hospital Reports and Journal of the Royal London Ophthalmic Hospital 1859; IX:October.

13 Swade D. The cogwheel brain. Charles Babbage and the quest to build the first computer. London: Little Brown, 2000.

14 Brewster D. Letter on fishes' eyes. British Library MS 37183.501824

15 Babbage C. Scriptores optici: or a collection of facts relating to optics. London: R Wilks, 1823 